\title{
A County Town in Ruins: Memories, Emotions, and Sense of Place in Post-Earthquake Beichuan, China
}

\author{
Lili Qian ${ }^{1} \oplus$, Chunhui Zheng ${ }^{2, *}$, Qin Lai ${ }^{1}$ and Juncheng Guo ${ }^{1}$ \\ 1 School of Business, Zhejiang University City College, Hangzhou 310015, China; qianll@zucc.edu.cn (L.Q.); \\ laiq@zucc.edu.cn (Q.L.); gjuncheng11@163.com (J.G.) \\ 2 School of Tourism, Guangzhou University, Guangzhou 510006, China \\ * Correspondence: chunhui863@163.com
}

Citation: Qian, L.; Zheng, C.; Lai, Q.; Guo, J. A County Town in Ruins: Memories, Emotions, and Sense of Place in Post-Earthquake Beichuan, China. Sustainability 2021, 13, 11258 https://doi.org/10.3390/su132011258

Academic Editor: Amir Khorram-Manesh

Received: 23 July 2021

Accepted: 4 October 2021

Published: 12 October 2021

Publisher's Note: MDPI stays neutral with regard to jurisdictional claims in published maps and institutional affiliations.

Copyright: (c) 2021 by the authors. Licensee MDPI, Basel, Switzerland. This article is an open access article distributed under the terms and conditions of the Creative Commons Attribution (CC BY) license (https:// creativecommons.org/licenses/by/ $4.0 /)$.

\begin{abstract}
Ruins serve as symbolic sites at which to re-examine people's relationships with the past and bonds with places. In the context of the ruination caused by earthquakes and the displacement and resettlement of local residents post-disaster, this paper explores vernacular (residents' and survivors') memories, emotions, and senses of place triggered by the ruins of Beichuan county town, China. Results show vernacular memories of specific ruins were highly fragmented and multi-temporal. Interwoven before- and after-quake memories gave rise to complex emotions, mainly including traumatic feeling of sadness, fear, and painful nostalgia. The study further identifies people's sense of place towards the ruined county town and finds that locals' sense of place was not accompanied by the loss of physical dependence to the negative side; locals still expressed high levels of place identity (physical uniqueness, self-esteem, and meanings), place attachment (rootedness and emotional attachment), and positive consequences of place behaviours (protection intention and revisiting) post-earthquake. Moreover, it found that sociodemographic variables of age and length of residence in Beichuan and the variables of disaster loss had significant effect on people's sense of place. This study balances the overriding focus on visual and representational concerns common in ruin scholarship and further reveals the complex psychological processes impacting on sense of place after large-scale disasters. The findings reflect on the relief practices of post-disaster planning and can serve to guide ruin preservation.
\end{abstract}

Keywords: ruin; memory; emotion; sense of place; earthquake

\section{Introduction: The Meanings and Senses of Ruins}

At 14:28 on 12 May 2008, a magnitude 8.0 earthquake struck Sichuan Province, China. The main earthquake, aftershocks, and secondary disasters affected 417 counties (cities, districts) in 10 provinces and caused 69,226 deaths, 17,923 missing persons, and 15,100,000 homeless. The total direct economic loss exceeded RMB 845 billion [1]. This earthquake is considered the most destructive since the People's Republic of China was established. Beichuan was one of the most destroyed areas, with 15,645 people killed and 4,311 people missing [2], and its centre was almost totally razed. Considering the potential risk of more destruction and local residents' safety, a relief plan was approved for the large-scale transfer of the wounded and local residents and to retain the town centre as an earthquake-ruined heritage site.

Despite the living- and production-related losses, these ruin spaces have fascinated scholars; their external characteristics trigger not only the 'aesthetic of absence' but also an aspiration to interpret the meanings behind the debris [3]. Serving as metaphors in contemporary society, ruins are endowed with special social and cultural meanings by diverse interest groups. For instance, governments have carefully preserved Beichuan ruins as social heritage site and have constructed a memorial center for the purpose of catastrophic event commemoration [1]. The local tourism industry sector constructed tourism facilities and turned Beichuan ruined town into an open-air museum for seismological education 
and dark tourism [2]. Migrants and former residents treat the ruins as a personal heritage site which reminds them of their past times and lost homes. Survivors and catastrophe descendants turn ruins into memorial sites where they mourn for passed relatives and friends. Whether for the authorized political purpose of commemoration, education, and tourism or the collective vernacular purposes of nostalgia and mourning, the complex relationships between ruins' physical remains and diverse groups of people clearly exist; however, how this relationship is possible is not self-evident [4]. While ruins' meanings are challenged and negotiated via diverse groups, the dominant discourse, in most instances, is driven by politics and social ideologies, leading to the undercutting of the other potential meanings and interpretations from ordinary people [5]. Meanwhile, much scholarly attention has been paid to ruins' visual/aesthetic value and their social and symbolic meaning [6]; numerous literatures focus on the regeneration and transient function, such as turning ruins to heritage sites and dark tourism sites [2]. Less attention has been paid to personal meanings from ordinary people who once lived in them. This leads to the neglect of ruins' inner, non-representational power of arousing memories and emotions and the underestimation of the value of these eradicated places' lived experiences [5].

Similar to other places, the memories, emotions, senses, and meanings associated with ruins are constructed by their former inhabitants. Just as place is deemed 'an incessant state of becoming' [7], memories, sense, and meaning may change with a place's physical characteristics accordingly, along with the bond between people and ruins. Lucas distinguished the 'slow' and 'fast' ruins [8]: Slow ruins are caused by a more gradual transition exacerbated by social or economic transitions or incremental abandonment, while fast ruins result from an abrupt transition, such as wartime devastation or natural disasters. If the ruination process is gradual, people are aware of the process; therefore, they can cope with it accordingly. However, if change is sudden and unexpected, such as in the case of the May 12 earthquake causing the destruction of an entire town and resulting in significant tragedy in Beichuan, people do not have the opportunity to gradually adjust to the changes. Thus, how does this affect people's bonds with places post-earthquake?

This paper explores residents' and survivors' perceptions and attitudes towards ruins to reveal the complex post-disaster relationship between locals and ruins. Specifically, it examines locals' vernacular memories, emotions, and senses of place triggered by ruins to balance the overriding focus on the visual and representational concerns that dominate ruin scholarship and investigates mega-disasters' lasting impacts that may influence the relationship between local residents and places. The findings can guide further research regarding local residents' bonds with ruins when ambiguous, conflicting, and negative experiences are involved. It also reflects on the relief practices of post-disaster planning and reconstruction.

\section{Literature Review: Post-Disaster Memories, Emotions, and Sense of Place}

\subsection{Memories and Emotions}

Memory is the mental capacity of storing facts, events, images, impressions, and the like, and it helps us preserve and recognise previous experiences [9]. One of memory's important features is its spatiality [10]. Memories unfold within spatial frameworks. Places, spaces, even ruins, called 'sites of memory' by Nora [11], serve as powerful symbols and memory repositories and act as autobiographical memory aids in self-formation [12]. Accordingly, memory is organised and aroused by spatial reference points, such as roads and landmarks, to help people identify where they are and build their own memories [9]. Although disasters can turn facilities into ruins and change memory's spatial reference points, what remains in one's mind is the former familiar place; for example, survivors still recognise homes and workplaces in Sichuan's post-earthquake ruins [13].

Another feature of memory is its socially constructed and collectively shared nature [14]. Although post-disaster memories differ according to social groups, this paper mainly focuses on the vernacular groups who lived in Beichuan and personally experienced the disaster and loss. According to Halbwachs's theory [14], the social constructed nature 
of memory refers to 'a reconstruction of the past in the light of the present', and it suggests that people will re-evaluate past experiences and re-construct memory in the present situation and social context. Meanwhile, according to Olick [15], the collective nature of memory means an aggregation of individuals' memories. Likewise, Lewicka [16] argues that vernacular memory is rooted in individuals' first-hand experiences of past events and narratives. Following this, some studies explored vernacular memory through a study of aggregation of personal memories and experiences in the context of post-disaster context. For instance, survivors of the Christchurch, New Zealand, earthquake often involuntarily recalled their pre-earthquake daily memories [17]. Catastrophic events cause personal flashbulb memory; survivors still remember in detail what they were doing several years after the September 11 terrorist attack [18]. As a form of cognitive memory, local residents' most unforgettable memories were the unimaginable loss and chaos after the Yasi cyclone [19].

The third feature of memory is its affective nature. Emotions often accompany cognitive memories. Survivors' post-disaster emotions have been extensively studied in the discipline of disaster psychology. Negative feelings of uncertainty, hopelessness, stress, anxiety, grief, depression, and disbelief are common among those who have experienced a high-impact disaster with great property loss [20-26]. For example, survivors living in a state of existential threat after cyclone Yasi experienced panic and fear for their lives [19]. Inhabitants in disaster area felt insecure, vulnerable, and desperate when living near the collapsed Morandi bridge in Italy [27]. Residents forced to relocate after Hurricane Katrina expressed nostalgia and yearning to return to former homes [28]. Meanwhile, many positive emotions, including connectedness, social cohesion, and cooperation [24], as well hope, renewal, and strength, were also present during the post-disaster relief period [29,30].

In trends of turning toward the past, memory serves as a significant psychological geography concern [10] to examine human-place/ruin relationships post-disaster [31]. Previous studies reveal that vernacular memories promoted community resilience [32,33] and the conservation and regeneration of ruined cities post-disaster [34]. However, what the memories are and how the memories make function post-disaster are not self-evident. Ruins function as containers of memory of former residents, and their non-representational power of arousing lived experiences, recollections, and emotions remain unclear in the postdisaster context. Meanwhile, memory's spatiality and multi-temporal and multi-affective nature needs to be further identified in the post-quake context.

\subsection{Sense of Place}

Significant environmental changes challenge people's well-being and emotional bonds with place [35]. As an overarching concept within the place literature, 'sense of place', which provides a useful framework in investigating human-place bonds, was introduced into disaster research to predict post-disaster human psychologies and recovery processes [24]. Despite the plethora concepts describing human -place relationships, sense of place is considered to be the most general concept, which has been employed to describe the beliefs, meanings, interpretations, attitudes, and behaviours that people associate with a particular place [36]. Previous studies have revealed that sense of place captures at least three narrower concepts which are frequently discussed in human geography and environmental psychology, namely, place attachment, place identity, and place dependence [36,37]. Although there is a considerable degree of overlap among the above concepts, they still have distinctive characteristics. Place attachment is commonly defined as people's emotional bonding to places [38]. Place identity refers to people's cognitive identity in relation to the physical environment [39]. Place dependence describes people's perceptions of whether or not he can satisfy his needs in a particular place compared to alternative places [40]. In addition, place behaviours, which mostly concern one's proenvironment behaviours and intimate action towards a place [38], have been considered significant dimensions of sense of place and have been widely discussed in place research.

Both natural and man-made disasters can dramatically destroy physical and social surroundings and alter people's familiar landscapes, prompting a disconnect between 
residents and their environment and provoking disorientation and loss of place [41]. Disasters destroy physical resources related to daily activities, depriving a place of its basic functions of dwelling and production and breaking one's place dependence and place-based comfort $[29,42]$. The loss of one's home and neighbourhood damages one's social ties and destroys an individual's belonging and place attachment [43]. It also undermines the places' capacity to symbolise central aspects of self [27] and leads to weakening self-perception and place identity [28]. Concepts of 'place attachment disruptions' [44] and 'place identity threat' [45] have been used to explain the sense of place in the environmental catastrophe context.

Although the majority of studies have revealed disaster's passive impacts on people's bonds with place and the negative side of sense of place post disaster, some studies have shown the positive aspects of sense of place. Milligan [46] argues that sense of place is an implicit psychological structure in daily life whose significance is overlooked. Once disaster threatens the people-place bond, loss of place tends to provoke strong social and psychological responses and raise the important meanings one has associated with a particular place. Chamlee and Storr's [47] study showed that after long-term experience of disasters and displacement, residents became more conscious of their place attachment and identity after Hurricane Katrina. Zheng et al. [26] found that locals' place dependence and place identity were restored 6 years after the Wenchuan earthquake in Chengdu, China. Smith and Cartlidge [48] argue that sense of place acts as an 'anchor' that reinforces a sense of belonging, personal attachment, and identity during place loss and suffering. Post-disaster positive place identity and attachment led to active behaviours, such as participating in relief work and devotion for the injured [24] and deciding to return to former disaster-stricken areas [47].

These studies illustrate the complex and conflicted nature of sense of place in postdisaster human-ruin relationships. Despite this, sense of place was used to predict risk perception [49], well-being [24], post-disaster resilience [21,47], relief and recovery coping [42], transformative adaptation [50], and the relocation intention of inhabitants [35,51], and it remains under-researched in the context of disasters [47,52]. Specifically, compared with growing literature discussing the positive consequences of sense of place, very few studies have examined the antecedents of it. How is sense of place affected by changes in psychological processes (cognition, affect, and behavior) after large-scale disasters [26]? How will disaster-based traumatic memories and emotions affect it? How will place-based nostalgic memories and emotions affect it? How will these conflicting and contradictory psychological process impact post-disaster sense of place? What are the features and extent of post-earthquake sense of place? Drawing on Proshansky et al.'s notion of sense of place that comprises clusters of individuals' positively and negatively valued memories, cognitions, and emotions related to physical settings [53], this paper proposes a "memoryemotion-sense of place" framework to examine the sense of place post-disaster and further reflect on the complex relationship between ruins and former residents' and survivors.

\section{Methodology}

\subsection{Study Site and Post-Earthquake Landscape}

Beichuan was one of the towns that suffered the greatest devastation after the 2008 earthquake in Sichuan Province. The earthquake, along with induced landslides, caused approximately $70 \%$ of the infrastructure in the county town of Beichuan, an area of $0.7 \mathrm{~km}^{2}$, to collapse [54]. Facing such huge property and life loss combined with the potential risk of more destruction, the local and central governments approved a relief plan to reconstruct the county centre in an open, safe area located $23 \mathrm{~km}$ from its original position while retaining the ruined town as an earthquake heritage site. According to the plan, the protection project preserved the entire town's layout and the ruins' spatial pattern to show typical seismic topography and an authentic earthquake landscape. The layout shows that most of the buildings and roads were buried by rocks and soil from nearby hills, with only certain buildings still identifiable (see Figure 1, points 1 to 34). At the foot of Jingjia Hill, an 
open space was chosen as a cemetery (see Figure 1, point 35). In front stands the memorial stone marking the time of the earthquake; pine trees and grass were planted to create quiet surroundings for public commemoration.

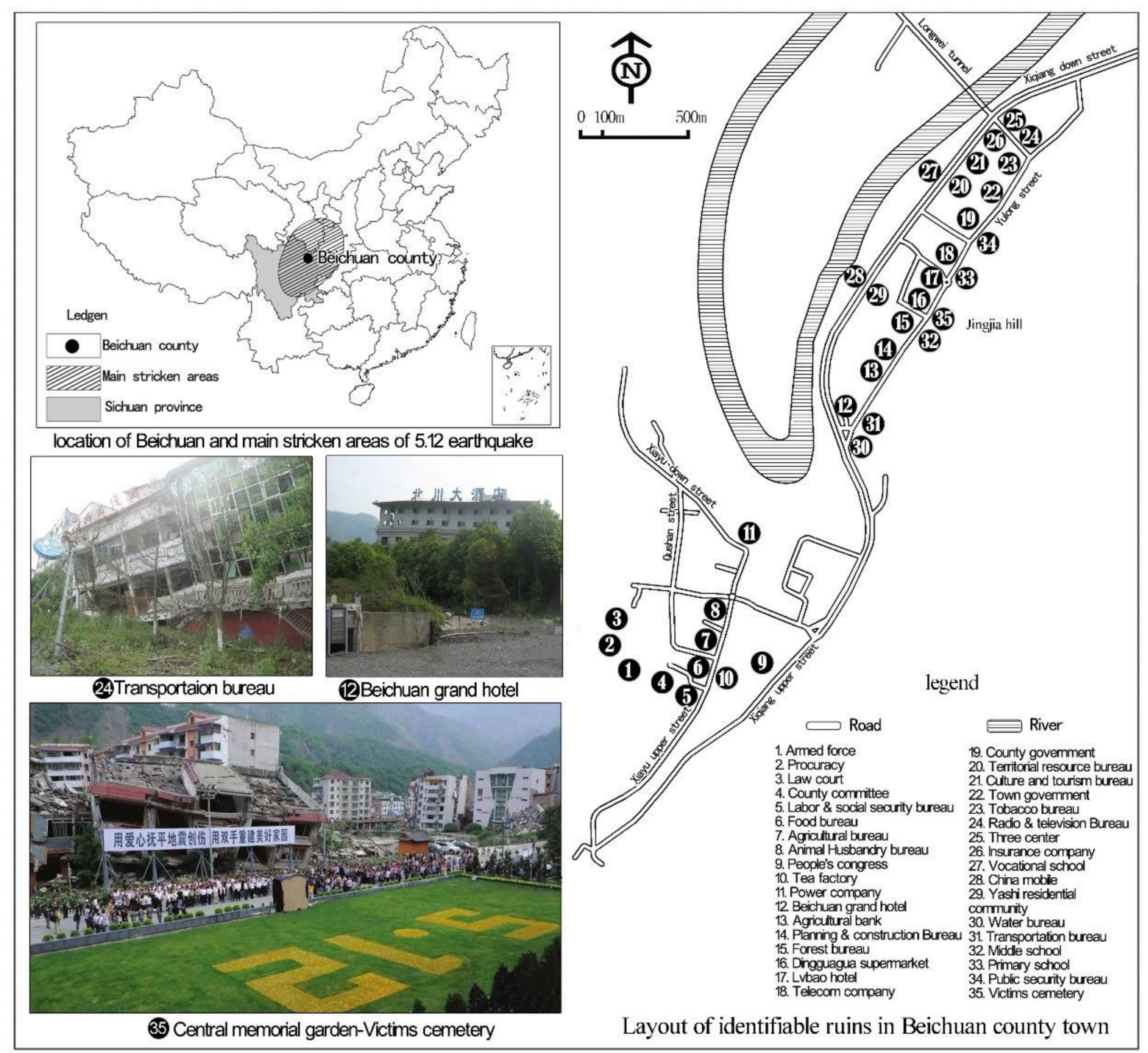

Figure 1. Layout of earthquake ruined county town of Beichuan.

\subsection{Method}

This study combines both a qualitative and quantitative approach in two stages. For the first stage, an open-ended questionnaire survey was conducted to discover locals' most unforgettable places, memories, and emotions involving the ruins. A total of 250 questionnaires were sent via convenience sampling, of which 191 valid responses were received. To further explore participants' living experiences pre- and post-earthquake and to understand the reasons behind such embodied memories, emotions, and sense of place towards the ruins, semi-structured interviews were also conducted. Of the 191 responses, 21 participants who were more expressive in the open-ended questionnaire stage were selected for further interviews, with each interview lasting about an hour. Their narratives were written down. The first stage occurred in May 2014. Several survey locations were chosen, including Beichuan and four nearby resettlement sites in the villages of Renjiaping, Dengjia, Jina Qiang, and Erma. As a majority of participants personally experienced the earthquake and had relatives and friends killed or injured, it was inevitable that the inter- 
view process could evoke traumatic memories and cause some degree of distress. Hence, we followed Muzaini's [55] survey method to support interviewees' psychological health. The participants were informed of the project and the possible effects prior to administering the interview. Once the individual agreed to participate, we began the interview process. If the participant experienced a high level of distress and needed a break, we stopped the interview and only continued when the participant indicated it was acceptable to do so. After the interview, we stayed in contact with some participants to ensure no long-term effects resulted from the interview.

For the study's second stage, a structured questionnaire survey was conducted to measure the extent of survivors' sense of place concerning the ruined county town. The questionnaire included 10 items measured using a 5-point Likert type scale and referred to the results from the first survey and interviews, as well as Williams and Roggenbuck's [37] scale of place attachment, Lalli's [56] scale of place identity, and Silver and Grek-Martin's [24] results of place behaviours post-disaster. This second stage was conducted in May 2015 at the same sites from the first stage. In total, 400 structured questionnaires were distributed, of which 321 were received as valid. Table 1 shows the sociodemographic profile of the first- and second-stage survey participants.

Table 1. Sociodemographic profile of participants.

\begin{tabular}{|c|c|c|c|}
\hline \multicolumn{2}{|c|}{ Sociodemographic Profiles } & \multirow{2}{*}{$\begin{array}{c}\text { Frist Survey }(\mathbf{N}=191) \\
84(44 \%)\end{array}$} & \multirow{2}{*}{$\frac{\text { Second Survey }(\mathbf{N}=\mathbf{3 2 1})}{153(48 \%)}$} \\
\hline & Male & & \\
\hline Gender & Female & $107(56 \%)$ & $168(52 \%)$ \\
\hline \multirow{4}{*}{ Age } & Under 20 years old & $5(2.6 \%)$ & $15(4.7 \%)$ \\
\hline & 20-39 years old & $90(47.1 \%)$ & $143(44.5 \%)$ \\
\hline & 40-60 years old & $81(42.4 \%)$ & $139(43.3 \%)$ \\
\hline & Over 60 years old & $15(7.9 \%)$ & $24(7.5 \%)$ \\
\hline \multirow{4}{*}{ Education } & Primary school and below & $40(20.9 \%)$ & $62(19.3 \%)$ \\
\hline & Junior middle school & $83(43.5 \%)$ & $115(35.8 \%)$ \\
\hline & High school & $46(24.1 \%)$ & $93(29 \%)$ \\
\hline & College and above & $22(11.5 \%)$ & $51(15.9 \%)$ \\
\hline \multirow{4}{*}{ Length of Residence } & Under 5 years & $49(25.7 \%)$ & $71(22.1 \%)$ \\
\hline & 5-10 years & $7(3.7 \%)$ & $47(14.6 \%)$ \\
\hline & $11-30$ years & $61(31.9 \%)$ & $124(38.6 \%)$ \\
\hline & Over 30 years & $74(38.7 \%)$ & $79(24.7 \%)$ \\
\hline \multirow{4}{*}{ Relatives died } & Died & $126(66 \%)$ & $237(73.8 \%)$ \\
\hline & None & $65(34 \%)$ & $84(26.2 \%)$ \\
\hline & None & $8(4.2 \%)$ & $25(7.8 \%)$ \\
\hline & Little & $10(5.2 \%)$ & $19(5.9 \%)$ \\
\hline \multirow[t]{3}{*}{ Economic loss } & Moderate & $20(10.5 \%)$ & $62(19.3 \%)$ \\
\hline & Less serious & $30(15.7 \%)$ & $67(20.9 \%)$ \\
\hline & Serious & $123(64.4 \%)$ & $148(46.1 \%)$ \\
\hline
\end{tabular}

During the data analysis stage, open coding and word frequency statistics were performed with the software Nvivo 11 to analyse the themes and domains based on the narratives from both the open-ended questionnaire surveys and semi-structured interviews. After indicating potential patterns and matching them with data, the coding process mainly generated themes of earthquake-associated places and memories and pre-earthquake daily life, as well as complex emotions towards specific sites and a sense of place towards Beichuan as a whole. Meanwhile, quantitative data analysis was performed with SPSS 21 and included basic frequency, means, and standard deviation analysis to identify the extent of participants' sense of place. Cronbach's alpha was also tested to evaluate the reliability of the indicators of each latent variable; Cronbach's alpha was 0.911, suggesting good reliability of the sense of place structural items. 


\section{Ruins Aroused Memories}

In the first open-ended questionnaire survey, participants were asked: 'Do you often recall ruined Beichuan? Which places do you remember most often? Why? What memories do these ruins trigger?' The 191 local survivors mentioned 420 sites (this includes repetitions of the same site) as the most often remembered. Of these sites, approximately half of them were daily life places where the participants had lived (22.5\%), participants' homes $(13.6 \%)$, and work/study places $(14.4 \%)$; meanwhile, the other half were the earthquakerelated places where the participants were, where they rescued others during the quake $(32 \%)$, and where their relatives and friends were either injured or killed (17.5\%) (Figure 2).

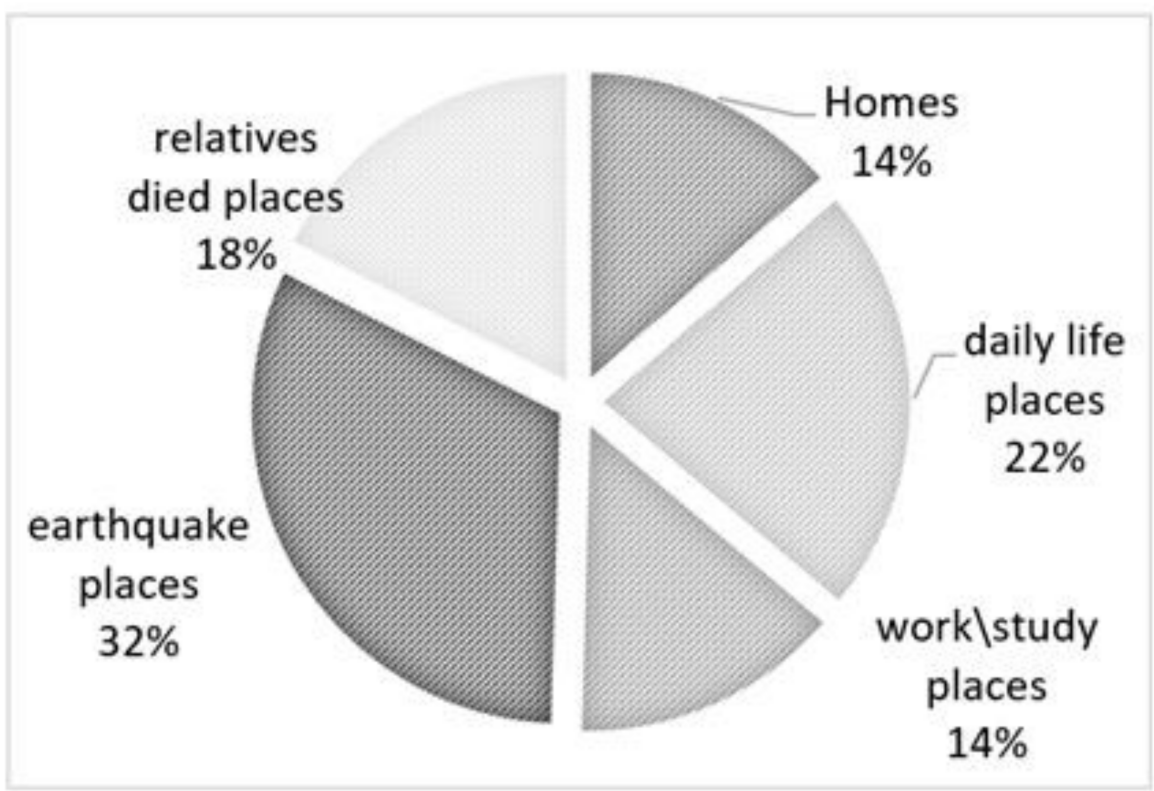

Figure 2. Categories and frequency of memorable sites.

\subsection{Daily Life Memories}

Ruins contain traces of previous times, lives, and experiences pre- and post-disaster. However, these traces are not visible to others; they are only visible to those who lived in and experienced these places before. Important social spaces, such as the Beichuan farmers' market, hospital, crossroads, bus station, Longwei Park, and specific neighbourhoods, were the places mentioned most frequently. Although most of these places were destroyed, their locations and place-related memories were still vivid in locals' minds. For example, the farmers' market was once the town's largest commercial centre, selling agricultural products, clothing, and daily necessities. A 48-year-old woman and 30-year resident of Beichuan said, 'I went to the market to buy food every day, and I chatted with friends sometimes. I could spend the whole morning there ... '. Many locals also worked there. According to a 40-year female resident, 'I sold my homegrown vegetables in the market every day. Although the work was hard and the earnings were little, I liked the busy, lively atmosphere, talking with acquaintances, exchanging information and gossip ... '. The market as a local, frequently used, and personal space in a small town is associated with collective day-to-day experiences and fond memories. These everyday spaces gain importance because they constitute one's routinised biographical traces and form part of one's life history [9], as well as bridging one's social ties with others [29].

However, these ordinary places' meanings and values tend to be overlooked until they lose their space, functions, and inhabitants, when their benefits and importance become apparent. As another 38-year-old male participant who lived over 30-year mentioned, 'My family and friends lived in Beichuan before the earthquake. Now, I often recall my living and working places, such as my home, the restaurant I ran, where I often invited my friends to eat, 
drink, and chat in, Longwei Park, where I often took my wife walking when she was pregnant. I used to think these places were ordinary and common, but since the earthquake, I now think these are places full of precious memories'. This coincides with Milligan's [46] view of the implicit psychological structure of daily life places and reveals ruins' power to arouse living memories and significant meanings associated with ordinary, common places taken for granted before disasters.

\subsection{Earthquake Memories}

The earthquake memories and their related places conjured loss, which left deep marks in local residents' minds. A 25-year-old man who attended high school in Beichuan for three years said, 'The unexpected earthquake is engraved in my bones. When it happened, we were having a Chinese lesson. The shaking was not very violent at first. We thought it was a large machine passing nearby. When the whole building shook hard, and trees rushed to the sky outside of the window, we suddenly realised it was an earthquake. We hid under the table immediately. Immediately after the earthquake, I jumped out the window and ran to the playground. Dust was everywhere, and many students were buried in the ruins ... My mind went blank... '. Just as Tuan [57] mentioned in his work on the landscapes of fear, large-scale natural disasters that take lives and cause enormous loss deeply impact people's memories. These flashbulb memories maintain great detail for specific experiences [3]; in the case of Beichuan, survivors can still recall exactly where they were, what they were doing, and where their loved ones were killed when the earthquake hit.

In addition to traumatic disaster memories, disaster coping and the relief effort immediately after the earthquake is also unforgettable. In interviews, many participants mentioned their personal experience of combating the earthquake and rescuing others. A 74-year-old male participant who lived for over 30 years in the town mentioned that 'buildings and infrastructure collapsed, many people were trapped in the ruins ... Everybody who luckily escaped voluntarily took part in rescuing the injured and victims, so without hesitation, I joined the relief work to pull the injured out and take them to safety ... even now I still clearly remember how much time I went back between the dangerous collapsing ruins. This process includes two times to kindergarten, five times to farmers' market, ten times to county government ... '. Large-scale disaster leads to place destruction and social disorder; however, residents' coping practices help them regain a sense of control, recover, and create new place meanings post-disaster [26]. These experiences construct positive memories that help re-establish people's bonds with places even when they have collapsed to ruins.

\section{Ruins Aroused Emotions}

In the first open-ended questionnaire survey, participants were then asked followup questions: 'What do you feel about these most unforgettable places? What is your emotional reaction towards these places? Results showed that almost two-thirds (62.5\%) of the emotions that participants expressed regarding the most unforgettable places were trauma-related, including negative feelings of sorrow $(46.5 \%)$ and fear $(16.1 \%)$, mostly related to earthquake memories. Almost one-third (30.4\%) of the emotions that participants expressed were nostalgia-related, including sympathy $(22 \%)$ and yearning $(8.4 \%)$. Positive feelings were also felt, including calmness (2.0\%), happiness (2.9\%), gratefulness $(1.4 \%)$, and pride $(1 \%)$. The types and frequency of the emotions are presented in Figure 3.

\subsection{Traumatic Emotions}

Trauma is a psycho-emotional reaction caused by exposure to upsetting losses and suffering involving feelings of pain, fear, distress, sorrow, and even physical symptoms, including headaches, sleep disturbances, and the like [58]. Thinking about the ruins and places where many died in the earthquake made people feel sad. Some of the most tragic places mentioned included the local schools, where many young, innocent lives were taken: "Children are "the flowers of the nation" and Beichuan's future. Tens of thousands of them were killed and buried with the sudden collapse of the school buildings ... Every time I pass by those school 
ruins, I can clearly recollect the harrowing scene and feel deep sorrow' (a 64-year-old man who lived in Beichuan for over 30 years). Places and ruins related to mass death corresponded to the residents' collective trauma, leading them to feel sorrow.

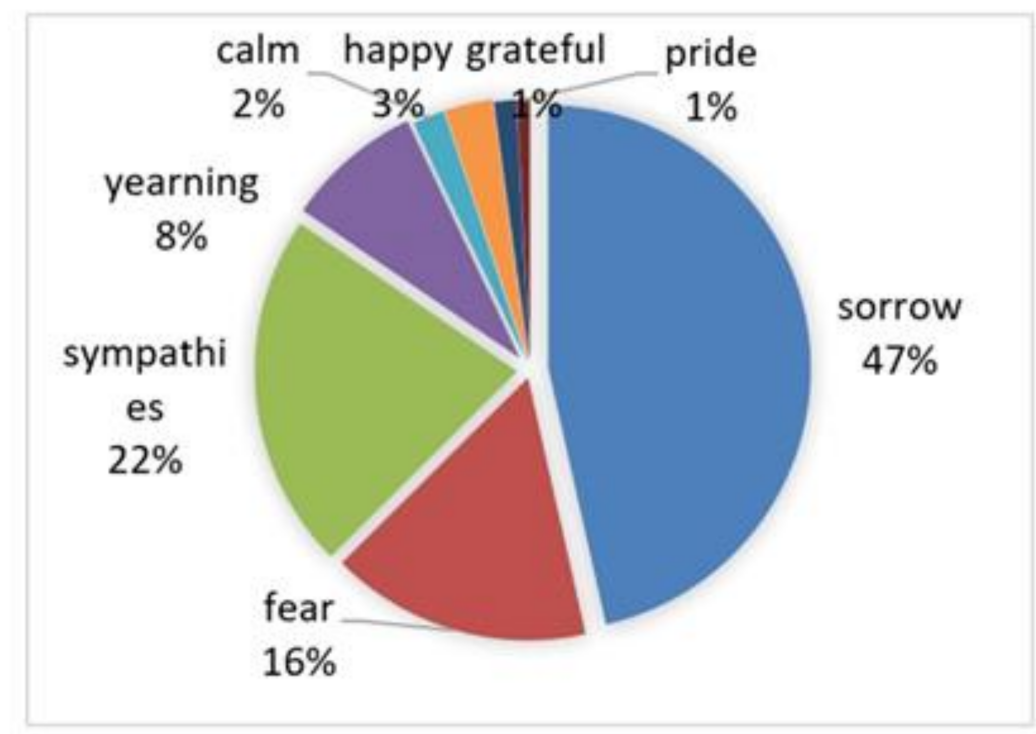

Figure 3. Categories and frequency of the emotions.

Furthermore, the places relatives and friends died caused tremendous grief, sorrow, and even fear: 'My father did business in the market, and he was killed there. When I see or recall this place, I feel very sad and even scared' (a 34-year-old woman who has lived in Beichuan for 20 years). The collapsed ruins aroused visions and memories of the earthquake, bringing fear to those who personally experienced the disaster: 'When the earthquake struck, I happened to be passing by the market. Luckily, I escaped, though I still feel fear every time I recall the place' (a 36-year-old man who lived in Beichuan for 10 years).

The memories of the earthquake and the traumatic emotions evoked do fade over time. As one person mentioned, 'I feel sad every time I remembered the quake several years ago. However, after a period of grief, I feel much calmer. Now I can rationally view the past people, places, and events. An earthquake is natural. Nobody can stop it, and loss is inevitable' (a 25-year-old woman who lived in Beichuan for 10 years). Yet, some are still unwilling to recall the terrible sights or recount their tales of the event. Avoiding places to escape traumatic memories, choosing not to remember, and trying to forget are effective ways to cure trauma. However, earthquake-related memories and places are not easy to avoid: Just as forgetting may be a conscious effort, memories may be triggered unconsciously [55].

\subsection{Nostalgic Emotions}

The term 'nostalgia' is used to describe a strong, painful longing to return to a home that no longer exists [59]. Locals often recall their environment and former homes and lives in Beichuan, and they sympathise with past places and times: 'Our family and many relatives once lived in old county town of Beichuan. The ecological environment there was more comfortable; we had a big house and a vegetable garden. Our granddaughter lived with us, and we had a happy life. After the earthquake, I don't often return to the ruins. But I still often recall the old county town and deeply wish for my past home and town' (a couple who lived in Beichuan for almost 50 years). Legg [60] argued that remnants and memory of the past trigger nostalgic yearning. Nostalgic feelings are more evident and arise when disaster leads to displacement and resettlement; they are expressed as a 'bittersweet' feeling for former places and a yearning for a cherished environment that has been lost or destroyed [61]. 
Deep nostalgia and attachment to old places lead to locals not being able to easily adapt to the new resettlement environment and a feeling of not being at home. A 60-yearold man who lived in Beichuan for more than 50 years described his nostalgia towards the old town: 'I often recall fragments of living in Beichuan before the earthquake: I feel everything in Beichuan is good, the landscape, the environment, the people, the neighbourhood ... I miss everything about the old town ... Although I have lived in a new town for many years, I still feel there is a disconnection between me and the new place. Without old relatives and friends, without my old home, I feel unable to integrate... '. Many others mentioned their yearning to live in the old town and would choose to live nearby if possible.

Furthermore, local survivors are not only nostalgic for past living and working places but also mourn for their past loved ones who died. At the ruins of a middle school, a white banner hangs to express a mother's deep yearning for her dead son. On the banner are pictures of her son and letters in memory of her son: 'Hechuan, do you live happily in heaven? Your father, sister, and I miss you a lot... Mother cannot come back to see you this year, but our hearts are together. Please forgive mother ... wherever we go, we do not forget you ... we are all together' (Figure 4).

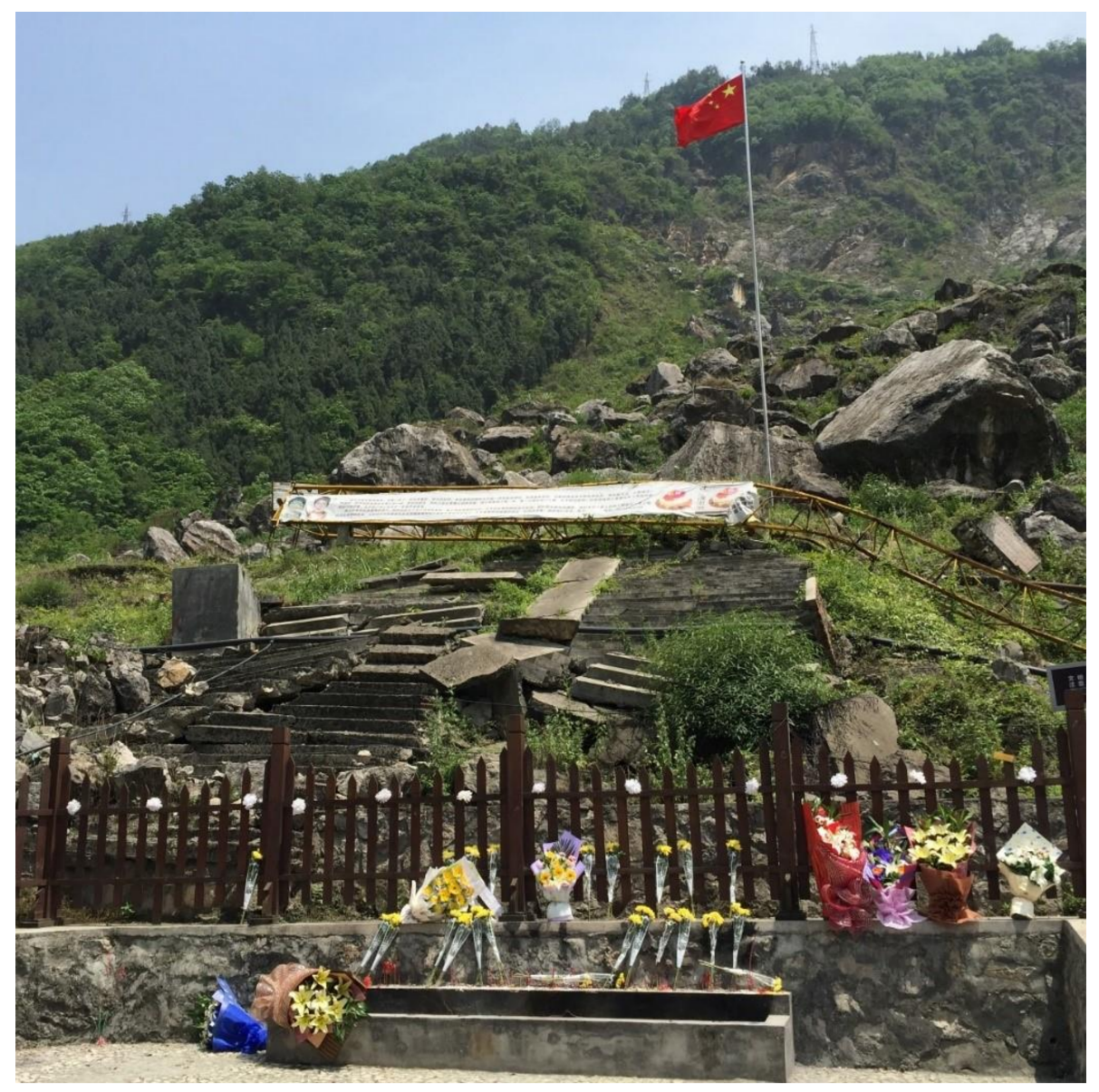

Figure 4. Ruins of Beichuan middle school and a banner hanging on the ruins.

\section{Sense of Place towards the Ruined County Town}

To understand survivors' and former residents' depth of sense of place towards the ruined country town, participants responded to 10 structured questions about place identity (distinctiveness, meaning, and self-esteem), place attachment (rootedness and emotional attachment), and place behaviour (protection intentions and revisit) with a 5-point Likerttype scale (5 = strongly agree and 1 = strongly disagree) (Table 2 ). Results showed that the means of place identity, place attachment, and place behaviors were above 4, suggesting 
a high level of sense of place towards Beichuan. The means of each item from high to low are place protection intentions $(\mathrm{M}=4.67)$, attachment $(\mathrm{M}=4.46)$, meaning $(\mathrm{M}=4.28)$, uniqueness $(M=4.20)$, rootedness $(M=4.14)$, self-esteem $(M=4.09)$, and revisit frequency $(\mathrm{M}=3.90)$.

Table 2. Measurement items and means of sense of place for post-disaster Beichuan.

\begin{tabular}{cllcc}
\hline Themes & Sub-Themes & \multicolumn{1}{c}{ Items } & Means & SD \\
\hline & Place identity & 4.18 & 0.92 \\
\hline Uniqueness & PI1: It is unique to me. & 4.20 & 0.83 \\
Meanings & PI2: It is meaningful and important to me. & 4.28 & 0.92 & 0.90 \\
\hline Self-esteem & PI3: It is my spiritual sustenance. & 4.09 & 0.91 \\
\hline & Place attachment & 4.30 & 0.86 \\
& PA1: My root is in it. & 4.14 & 0.87 \\
\hline Rootedness & PA2: I have a deep attachment to it. & 4.46 & 4.33 & 0.67 \\
\hline & Place behaviors & 4.66 & 0.91 \\
& Protection & PI1: I hope it will be preserved. & 4.60 & 0.92 \\
intentions & PPI2: I'd like to take part in protection action. & 4.57 & 0.94 \\
& PPI3: I would like to donate money for it. & 3.92 & 1.09 \\
& PR1: I come back often. & 3.88 & 1.13 \\
\hline
\end{tabular}

An analysis of variance (ANOVA) was carried out to identify the differences in the sense of place (place identity, place attachment, place behaviour) among residents who differed by gender, age, education, length of residence in Beichuan, relatives died, and economic loss at quake. The results are presented in Table 3 and show that the sociodemographic variables of gender and education did not significantly affect the differences in means of sense of place; however, the variables of age, length of residence in Beichuan, relatives died, and economic loss at quake significantly affect the differences in the means of sense of place. It found that the older the age, the stronger the place identity and place attachment, and the longer that residents lived in Beichuan, the stronger the place identity, place attachment, and place behavior intention. Residents who suffered a deeper level of loss in personal and property casualties (relatives died and economic loss) feel the stronger sense of place identity, place attachment, and place behaviour.

Table 3. Results of ANOVA and mean differences of sense of place among residents.

\begin{tabular}{ccccccc}
\hline & \multicolumn{2}{c}{ Place Identity } & \multicolumn{2}{c}{ Place Attachment } & \multicolumn{2}{c}{ Place Behaviors } \\
\cline { 2 - 7 } & Means & F & Means & F & Means & F \\
\hline Gender & & 0.06 & & 0.01 & & 0.03 \\
Male & 4.20 & & 4.30 & & 4.33 & \\
Female & 4.18 & & 4.31 & & 4.32 & \\
Age & & $11.38^{* * *}$ & & $16.49 * * *$ & & 1.61 \\
Under 20 years old & 3.04 & & 3.00 & & 3.96 & \\
20-39 years old & 4.11 & & 4.19 & & 4.33 & \\
40-60 years old & 4.33 & & 4.50 & & 4.36 & \\
Over 60 years old & 4.57 & & 4.67 & & 4.38 & \\
Education & & 0.40 & & & & \\
Primary school and below & 4.29 & & 4.04 & & 4.29 & \\
Junior middle school & 4.17 & & 4.30 & & 4.29 & \\
High school & 4.13 & & 4.25 & & 4.27 & \\
College and above & 4.21 & & 4.21 & & 4.38 & \\
\hline
\end{tabular}


Table 3. Cont.

\begin{tabular}{ccccccc}
\hline & \multicolumn{2}{c}{ Place Identity } & \multicolumn{2}{c}{ Place Attachment } & \multicolumn{2}{c}{ Place Behaviors } \\
\cline { 2 - 7 } & Means & F & Means & F & Means & F \\
\hline Length of Residence & & $36.23^{* * * *}$ & & $48.64^{* * *}$ & & $12.73^{* * * *}$ \\
Under 5 years & 3.38 & & 3.40 & & 3.98 & \\
5-10 years & 3.88 & & 4.00 & & 4.18 & \\
11-30 years & 4.37 & & 4.59 & & 4.35 & \\
Over 30 years & 4.82 & & 4.90 & & 4.69 & \\
Relatives died & & $27.81^{* * *}$ & & $26.66^{* * *}$ & & $13.53^{* * * *}$ \\
Died & 4.34 & & 4.45 & & 4.41 & \\
None & 3.75 & & 3.88 & & 4.10 & \\
Economic loss & & $16.03^{* * * *}$ & & $24.07^{* * *}$ & & $4.99^{* *}$ \\
None & 3.17 & & 3.22 & & 4.13 & \\
Little & 3.47 & & 3.29 & & 3.85 & \\
Moderate & 4.11 & & 4.28 & & 4.25 & \\
Less serious & 4.28 & & 4.38 & & 4.29 & \\
Serious & 4.44 & & 4.59 & & 4.47 & \\
\hline$* * * 000, * * p<0.05$. & & & & &
\end{tabular}

\subsection{Place Identity}

Pre-earthquake perceived physical uniqueness: Place uniqueness usually refers to the place-related physical landscapes, geographical environment, culture, and regional life which support one's physical dependence and help identify oneself with others and establish one's place-based identity [62]. Although the earthquake damaged the entire town, eliminating its basic function as a dwelling and the material characteristics of place dependence, the old, ruined town still provides positive memories for local survivors. As a 30-year-old woman described it, 'Compared with big, modern cities, the environment here was better, and the people were nice and sincere ... It is important, unique, and irreplaceable to me ... '. Beichuan is surrounded by green hills on three sides, and a river passes through it, making it comfortable for living. Additionally, the pre-earthquake economic and social conditions were better than other nearby county towns: 'Beichuan had abundant agricultural resources and related products and a large agricultural market ... Many people from the countryside, villages, and nearby counties came to sell and buy products... This town was once very prosperous, and we are very proud of it' (A 50-year-old man who lived in Beichuan for five years). Beichuan's geography, environment, and social advantages were its source of place uniqueness. Despite losing its capacity to provide living conditions for local residents, Beichuan's positive lifestyle is often remembered by many residents, who involuntarily compare it to their new living conditions after resettling. Many people thought the old country town was better for living than their new one.

Tragedy-based self-esteem: Place and environment provide support for one's selfesteem, which is central to building one's place identity, and self-esteem can be stimulated not only through comfortable, positive conditions but also through reference to a tragic place and ruins [13]. Locals' earthquake experiences, especially their coping and rescue actions, led to a strong sense of solidarity and community. Even people who were wounded in the earthquake and who struggled to survive and be optimistic after the earthquake show a high sense of self-esteem and act as role models, providing spiritual support for traumatised Beichuan survivors. One participant mentioned, 'Many people lost their relatives in earthquake, some were injured or disabled, but they still have self-worth and an optimistic outlook ... I think the Beichuan people are strong and brave ... Now our ruined county town is protected as an open-air seismological museum and tourism site, I hope every Chinese person sees it and recognises how our Beichuan people fought against the disaster and coped with relief work and how we struggled to survive' (a 65-year-old woman who lived in old Beichuan for over 50 years and suffered serious loss and injury). The place where tragedy struck and the disaster coping process and struggle to carry on after the earthquake helped locals create positive self-worth and high levels of self-esteem, which form their new, positive place 
identity. This result echoed with Zheng et al.'s [26] finding that post-disaster relief coping can enhance place dependence and place identity.

Ruins carrying meanings of commemorating dead loved ones: Meaning is central to a place's value [63]. Earthquakes change places' physical forms as well as their functions and bring to the fore the significant meanings locals associate with the ruins. Through tragedy, Beichuan gained new meanings. The ruins of Beichuan county town were protected as an earthquake heritage for remembering the disaster and its victims, a process Foote called 'place sanctification' [64]. This sanctification involved the creation of sacred center of memorial garden with a durable marker of memorial stone, which is set apart from its surroundings and dedicated to the memory of the earthquake and victims [13] (see Figure 1, point 35). For the vernacular groups, Beichuan was the last place where their deceased relatives had lived, as well as being where they go to mourn them. Serving as a shrine, the ruined county town functions as a way for the dead and living to communicate. In traditional Chinese Buddhist culture, when relatives die, it is believed that they go to the afterlife where they can listen to surviving loved ones pray and continue to care for them. One participant mentioned, 'The Central Memorial Garden is a mass grave where more than 10,000 victims are buried, [including] my son, grandson, and brother. Now only my wife and I are left, how I wish my son and grandson were still alive ... A few years after the earthquake, we miss them a lot ... Every year on May 12 (Earthquake Memorial Day), the Qingming Festival (Traditional Chinese Memorial Day for Dead Families), and my son's birthday, we light candles, burn paper money, and bring their favourite meals [to the memorial garden] to commemorate them.' Beichuan and its mass grave will now be home for the earthquake's victims forever, as well as a special place where locals feel a connection with deceased relatives to express their grief and engage with their sense of place through commemorating their loved ones. This is consistent with Wang et al.'s [65] finding that at another earthquake-stricken area, Yinxiu, locals felt a stronger sense of meaning and belonging to places where their significant others died or were buried.

\subsection{Place Attachment}

Rootedness and emotional attachment: The places we inhabit and frequently use correspond to deep emotional attachments for us [37]. Long-term residence in Beichuan pre-earthquake and personal experiences with day-to-day places became the source of locals' sentimental attachment towards its ruins. Despite tremendous loss and pain, forced relocation, and numerous traumatic emotions towards specific sites post-earthquake, participants still expressed feelings of rootedness and deep attachment towards the entire ruined town. Many stated that the old town means a great deal to them and holds an irreplaceable place in their lives. One participant recalled his life in old Beichuan pre-earthquake: 'At 32, I went to Beichuan to make a living, until at 57, the earthquake hit. I have witnessed great change and development in the town's economy and appearance ... Beichuan also witnessed my personal and family development, from beginning farming to my later small business, and from renting to buying a house... Living in the old county town for nearly 30 years made me take root here, and I have deep affection towards it' (a 64-year-old man). As Tuan [63] asserted, people will put down roots and build attachments to places where they were born, grew up, worked and lived in, and had particularly meaningful experiences. Meanwhile, these deep feelings of rootedness and attachment provide people with a sense of belonging, continuity, and spiritual fulfilment when living in transitional places and enduring hardships [24,29].

\subsection{Place Behaviours}

Ruin protection intention and revisiting: While positive place identity and attachment post-disaster can lead to active behaviours, such as taking part in relief and rebuilding work [24], negative place identity and attachment can make people afraid, uneasy, and want to escape from the place [55]. In the case of the Beichuan ruins, although participants expressed traumatic emotions towards specific earthquake-related places, they still had a positive sense of place, which included a high level of place identity (uniqueness, 
self-esteem, and meanings) and place attachment (rootedness and emotional attachment), resulting in positive place-based behaviours towards the ruins. These behaviours included place protection intention and revisiting the site, reflecting a kind of behavioural exclusivity of the ruined Beichuan county town in relation to alternative places. The structured questionnaires showed that, on the one hand, participants want the ruined town to be well preserved and would like to participate in protection actions and even donate money to preserve it; on the other hand, they often visit with relatives to commemorate the dead and express nostalgia for the ruined county town of Beichuan. Although most revisits occur on 12 May and during the Qingming Festival, residents often remember and talk about the ruins. Many have chosen to live nearby so as not to leave the ruined town.

\section{Conclusions}

The earthquake on 12 May 2008 destroyed Beichuan county town and dramatically changed the physical characteristics of its places and landscapes. Governments, the official relief plan, and the local tourism sector have played a part in the creation of the ruins' symbolic meaning through the process of selecting favoured place memories and articulating official representations. However, for survivors and former residents, the ruins' meanings, memories, and feelings remain underresearched. This paper explores locals' (residents and survivors) vernacular memories, emotions triggered by ruins, and senses of place towards the ruined county town to reveal the complex relationships between ruins and people post-disaster.

Our research reveals that locals' memories and emotions are highly fragmented, multi-dimensional, and multi-temporal. These memories and emotions towards specific ruined sites include locals' shared loss and tragedy related with large-scale disaster of earthquake, as well as fond memories of Beichuan's unique and prosperous geographical environment and collective day-to-day life memories. The memorable daily life sites and earthquake-related sites and pre- and post-earthquake memories are interwoven, giving rise to complex emotions such as sorrow, fear, sympathy, yearning, happiness, gratitude, and pride. Among these emotions, trauma caused by landscapes of fear and loss of loved ones, as well as nostalgia for former homes and past ones were the main feelings triggered by specific ruin sites.

Furthermore, our study identified the dimensions, extent, and influence factors of sense of place towards the whole ruined county town of Beichuan post-quake. Sense of place mainly comprises three parts: (1) place identity, including the sub-dimensions of pre-earthquake Beichuan's perceived physical uniqueness, tragedy-based self-esteem built from local residents' experiences of coping and struggle post-disaster, and the ruins' meanings related to commemorating dead loved ones; (2) place attachment, referring to the rootedness and emotional attachment to the old county town of Beichuan; and (3) place-based behaviours, including intentions to protect ruins and revisiting. The results showed that physical environment changes and loss of place dependence did not lead locals' sense of place to the negative side post-earthquake. Sociodemographic variables of age and length of residence in Beichua, as well as the level of disaster loss, significantly affect people's sense of place. It showed that the older the age, the stronger the place identity and place attachment; and the longer that residents lived in Beichuan, the stronger the place identity, place attachment, and place behavior intention. Residents who suffered a deeper level of loss in personal and property casualties (relatives died and economic loss) feel a stronger sense of place.

Third, drawing on Proshansky et al.'s viewpoint that sense of place comprises clusters of individuals' positively and negatively valued memories, cognitions, and emotions related to physical settings [53], this paper proposes a "memory-emotion-sense of place" framework (Figure 5) to reveal the complex relationship between ruins and former residents' and survivors. It finds that multi-temporal and conflicting memories (pre-quake daily life memories and post-quake memories) and multi-level and contradictory emotions (nostalgic emotions and traumatic emotions) both contribute to sense of place. Despite 
locals' negatively valued earthquake memories and traumatic responses to their ruined memorable sites, they still express high levels of positive place identity, place attachment, and place behaviours.

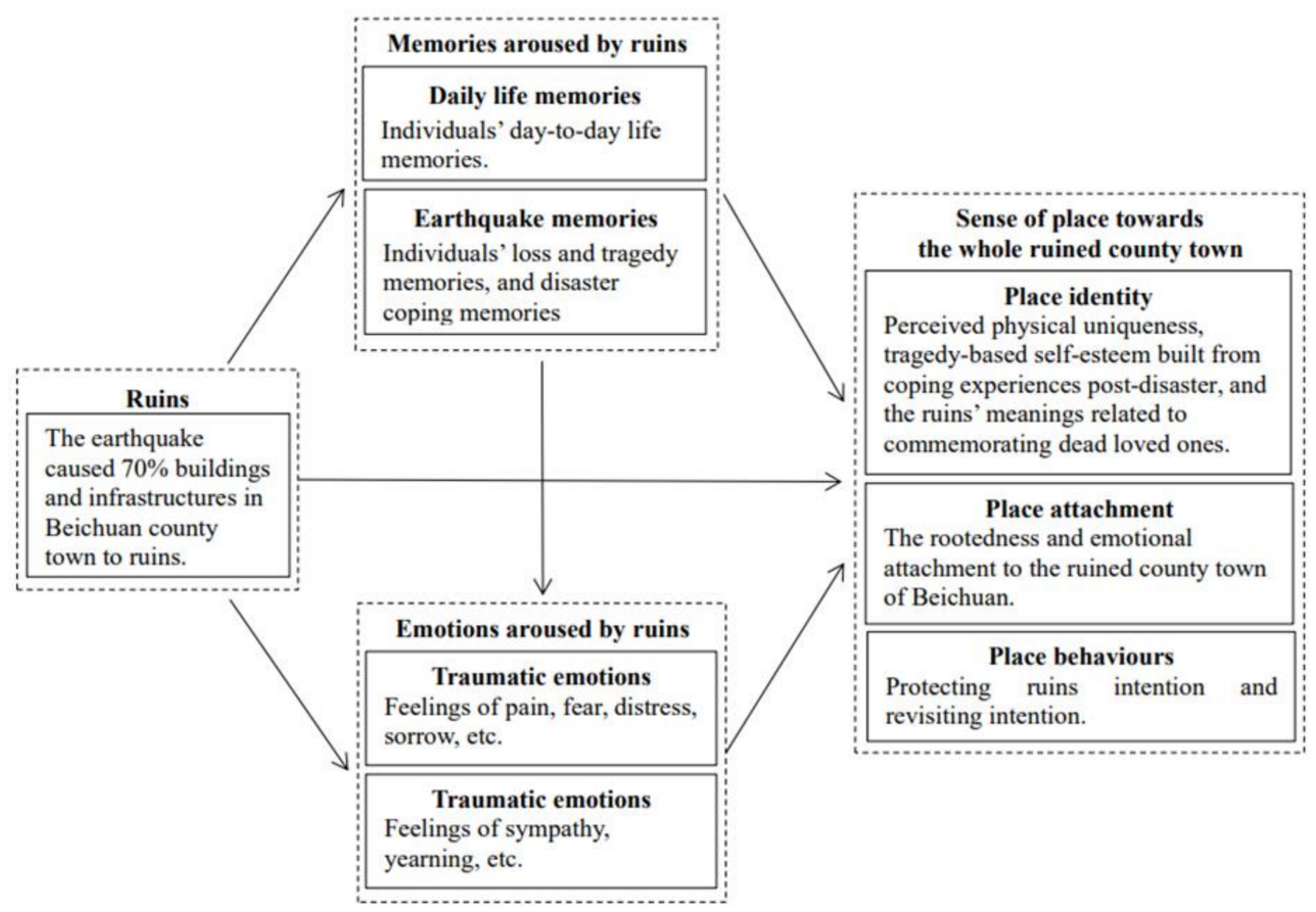

Figure 5. Memories, emotions, and sense of place towards ruins.

In general, post-disaster ruins serve as symbolic sites at which to re-examine relationships between the past and the present and bonds between former residents and places. The results suggest that memories and affective bonds between locals and places were influenced by the major event (earthquake); however, they were also affected by the ordinary experience of daily life, which acted as an implicit psychological structure of sense of self and place [46]. Disaster, loss, and tragedy trigger places to have significance and give places new meanings and sometimes tragedy-based place-esteem. It challenges views of 'place attachment disruptions' [44] and 'place identity threat' [45]. To some extent, it echoes views of 'growth following adversity' [22] following tremendous loss and post-disaster suffering and shows the positive side of place attachment, place identity, and place behaviours. This study balances the overriding focus on visual and representational concerns common in ruin scholarship through revealing the multi-level, multi-temporal, fragmented, and conflicting features of memories and emotions triggered by ruins. Furthermore, by investigating the connections among ruin-aroused memories, emotions, and senses of place, it contributes to reveal the complex psychological processes impacting on sense of place after large-scale disasters. From a post-disaster relief and reconstruction perceptive, local residents and survivors ensure the ruins live on, even when official representations rarely consider their place meaning, memories, emotions, and senses. Hence, we emphasise respecting those who have passed, listening to those who have survived, and treating the 
past as a dynamic resource as we protect the ruins that were once a vibrant town and work to construct the new town.

Author Contributions: Conceptualization, L.Q. and C.Z.; methodology, Q.L.; software, J.G.; validation, L.Q., C.Z. and Q.L.; formal analysis, L.Q.; investigation, L.Q. and C.Z; resources, L.Q.; data curation, L.Q.; writing-original draft preparation, L.Q., C.Z., Q.L. and J.G.; writing-review and editing, L.Q., C.Z., Q.L. and J.G.; visualization, J.G.; supervision, C.Z.; project administration, L.Q. and C.Z.; funding acquisition, L.Q. and C.Z. All authors have read and agreed to the published version of the manuscript.

Funding: This research was funded by National Natural Science Foundation of China (NSFC) [grant numbers 41901175, 41801135] and Zhejiang Philosophy and social science planning project [21NQN295YB], and Research Center of Digital Transformation and Social Responsibility Management, ZUCC.

Institutional Review Board Statement: The study was conducted according to the guidelines of the Declaration of Helsinki, and approved by the Institutional Review Board of Research Center of Digital Transformation and Social Responsibility Management, ZUCC, China.

Informed Consent Statement: Informed consent was obtained from all subjects involved in the study.

Data Availability Statement: Not applicable.

Conflicts of Interest: The authors declare no conflict of interest.

\section{References}

1. Dunford, M.; Li, L. Earthquake reconstruction in Wenchuan: Assessing the state overall plan and addressing the 'forgotten phase'. Appl. Geogr. 2011, 31, 998-1009. [CrossRef]

2. Qian, L.; Zhang, J.; Zhang, H.; Zheng, C. Hit close to home: The moderating effects of past experiences on tourists' on-site experiences and behavioral intention in post-earthquake site. Asia Pac. J. Tour. Res. 2017, 22, 936-950. [CrossRef]

3. Marschall, S. Touring memories of the erased city: Memory, tourism and notions of 'home'. Tour. Geogr. 2015, 17, 332-349. [CrossRef]

4. Trigg, D. The place of trauma: Memory, hauntings, and the temporality of ruins. Mem. Stud. 2009, 2, 87-101. [CrossRef]

5. DeSilvey, C.; Edensor, T. Reckoning with ruins. Prog. Hum. Geogr. 2013, 37, 465-485. [CrossRef]

6. Garrett, B. Book review. Ruins of Modernity by Julia Hell \& Andreas Schonle. Environ. Plan. D Soc. Space 2011, 29, 378-380.

7. Pred, A. Place as historically contingent process: Structuration and the time-geography of becoming places. Ann. Assoc. Am. Geogr. 1984, 74, 279-297. [CrossRef]

8. Lucas, G. Modern ruins. In Oxford Handbook of the Archaeology of the Contemporary Past; Graves-Brown, P., Harrison, R., Piccini, A., Eds.; Oxford University Press: Oxford, UK, 2013.

9. Osborne, B.S. Landscapes, memory, monuments, and commemoration: Putting identity in its place. Can. Ethn. Stud. 2001, 33, 39.

10. Hoelscher, S.; Alderman, D. Memory and place: Geographies of a critical relationship. Soc. Cult. Geogr. 2004, 5, 347-355. [CrossRef]

11. Nora, P. Between memory and history: Les lieux de mémoire. Representations 1989, 26, 7-24. [CrossRef]

12. Butler, A.; Knez, I.; Åkerskog, A.; Herlin, I.S.; Sang, Å.O.; Ångman, E. Foraging for identity: The relationships between landscape activities and landscape identity after catastrophic landscape change. Landsc. Res. 2019, 44, 303-319. [CrossRef]

13. Zhang, X.J. Heritage, Identity and Sense of Place in Sichuan Province After the 12 May Earthquake in China; University of London: London, UK, 2013.

14. Halbwachs, M. On Collective Memory; University of Chicago Press: Chicago, IL, USA, 1992.

15. Olick, J. Collective memory: The two cultures. Sociol. Theory 1999, 17, 333-348. [CrossRef]

16. Lewicka, M. Place attachment, place identity, and place memory: Restoring the forgotten city past. J. Environ. Psychol. 2008, 28, 209-231. [CrossRef]

17. Adams-Hutcheson, G. Spatialising skin: Pushing the boundaries of trauma geographies. Emot. Space Soc. 2017, 24, 105-112. [CrossRef]

18. Baptist, K.W. Incompatible identities: Memory and experience at the national September $9 / 11$ memorial and museum. Emot. Space Soc. 2015, 16, 3-8. [CrossRef]

19. Woods, C.; West, C.; Buettner, P.; Usher, K. “Out of our control”: Living through Cyclone Yasi. Int. J. Qual. Stud. Health Well-Being 2014, 9, 19821. [CrossRef] [PubMed]

20. Cox, R.S.; Perry, K.-M.E. Like a fish out of water: Reconsidering disaster recovery and the role of place and social capital in community disaster resilience. Am. J. Community Psychol. 2011, 48, 395-411. [CrossRef]

21. Klockow, K.E.; Peppler, R.A.; McPherson, R.A. Tornado folk science in Alabama and Mississippi in the 27 April 2011 tornado outbreak. GeoJournal 2014, 79, 791-804. [CrossRef] 
22. Knez, I.; Butler, A.; Sang, Å.O.; Ångman, E.; Sarlöv-Herlin, I.; Åkerskog, A. Before and after a natural disaster: Disruption in emotion component of place-identity and wellbeing. J. Environ. Psychol. 2018, 55, 11-17. [CrossRef]

23. Oulahen, G.; Doberstein, B. Citizen participation in post-disaster flood hazard mitigation planning in Peterborough, Ontario, Canada. Risk Hazards Crisis Public Policy 2012, 3, 1-26. [CrossRef]

24. Silver, A.; Grek-Martin, J. "Now we understand what community really means": Reconceptualizing the role of sense of place in the disaster recovery process. J. Environ. Psychol. 2015, 42, 32-41. [CrossRef]

25. McKinzie, A.E. You don't miss it 'til it's gone: Insecurity, place, and the social construction of the environment. Environ. Sociol. 2018, 5, 232-242. [CrossRef]

26. Zheng, C.; Zhang, J.; Guo, Y.; Zhang, Y.; Qian, L. Disruption and reestablishment of place attachment after large-scale disasters: The role of perceived risk, negative emotions, and coping. Int. J. Disaster Risk Reduct. 2019, 40, 101273. [CrossRef]

27. Rania, N.; Coppola, I.; Martorana, F.; Migliorini, L. The collapse of the Morandi Bridge in Genoa on 14 August 2018: A collective traumatic event and its emotional impact linked to the place and loss of a symbol. Sustainability 2019, 11, 6822. [CrossRef]

28. Morrice, S. Heartache and Hurricane Katrina: Recognising the influence of emotion in post-disaster return decisions. Area 2013, 45, 33-39. [CrossRef]

29. Scannell, L.; Cox, R.S.; Fletcher, S. Place-based loss and resilience among disaster-affected youth. J. Community Psychol. 2017, 45, 859-876. [CrossRef]

30. Cloke, P.; Conradson, D. Transitional organisations, affective atmospheres and new forms of being-in-common: Post-disaster recovery in Christchurch, New Zealand. Trans. Inst. Br. Geogr. 2018, 43, 360-376. [CrossRef]

31. Wilson, G.A. Community resilience, social memory and the post-2010 Christchurch (New Zealand) earthquakes. Area 2013, 45, 207-215. [CrossRef]

32. McEwen, L.; Garde-Hansen, J.; Holmes, A.; Jones, O.; Krause, F. Sustainable flood memories, lay knowledges and the development of community resilience to future flood risk. Trans. Inst. Br. Geogr. 2016, 42, 14-28. [CrossRef]

33. McKinnon, S.; Gorman-Murray, A.; Dominey-Howes, D. 'The greatest loss was a loss of our history': Natural disasters, marginalised identities and sites of memory. Soc. Cult. Geogr. 2016, 17, 1120-1139. [CrossRef]

34. Ardakani, M.K.; Oloonabadi, S.S.A. Collective memory as an efficient agent in sustainable urban conservation. Procedia Eng. 2011, 21, 985-988. [CrossRef]

35. Adams-Hutcheson, G. Stories of Relocation to the Waikato: Spaces of Emotion and Affect in the 2010/2011 Canterbury Earthquakes, Aotearoa New Zealand. Ph.D. Thesis, University of Waikato, Hamilton, New Zealand, 2014.

36. Jorgensen, B.S.; Stedman, R.C. Sense of place as an attitude: Lakeshore owners attitudes toward their properties. J. Environ. Psychol. 2001, 21, 233-248. [CrossRef]

37. Von Wirth, T.; Grêt-Regamey, A.; Moser, C.; Stauffacher, M. Exploring the influence of perceived urban change on residents' place attachment. J. Environ. Psychol. 2016, 46, 67-82. [CrossRef]

38. Lewicka, M. Place attachment: How far have we come in the last 40 years? J. Environ. Psychol. 2011, 31, 207-230. [CrossRef]

39. Proshansky, H.M. The city and self-identity. Environ. Behav. 1978, 10, 147-169. [CrossRef]

40. Stokols, D.; Shumaker, S.A. People in places: A transactional view of settings. In Cognition, Social Behaviour, and the Environment; Harvey, J., Ed.; Erlbaum: Mahwah, NJ, USA, 1981.

41. Calgaro, E. If you are vulnerable and you know it raise your hand: Experiences from working in post-tsunami Thailand. Emot. Space Soc. 2015, 17, 45-54. [CrossRef]

42. Devine-Wright, P. Rethinking NIMBYism: The role of place attachment and place identity in explaining place-protective action. J. Community Appl. Soc. Psychol. 2009, 19, 426-441. [CrossRef]

43. Fullilove, M.T. Psychiatric implications of displacement: Contributions from the psychology of place. Am. J. Psychiatry 1996, 153, 1516-1523. [CrossRef]

44. Brown, B.; Perkins, D.D. Disruptions in place attachment. In Place Attachment. Human Behavior and Environment. Advances in Theory and Research; Altman, I., Low, S.M., Eds.; Springer: Boston, MA, USA, 1992; Volume 12.

45. Hugh-Jones, S.; Madill, A. The air's got to be far cleaner here: A discursive analysis of place-identity threat. Br. J. Soc. Psychol. 2009, 48, 601-624. [CrossRef]

46. Milligan, M.J. Interactional past and potential: The social construction of place attachment. Symb. Interact. 1998, 21, 1-33. [CrossRef]

47. Chamlee-Wright, E.; Storr, V.H. "There's no place like New Orleans": Sense of place and community recovery in the ninth ward after Hurricane Katrina. J. Urban Aff. 2009, 31, 615-634. [CrossRef]

48. Smith, J.S.; Cartlidge, M.R. Place attachment among retirees in Greensburg, Kansas. Geogr. Rev. 2011, 101, 536-555. [CrossRef] [PubMed]

49. Bonaiuto, M.; Alves, S.; de Dominicis, S.; Petruccelli, I. Place attachment and natural hazard risk: Research review and agenda. J. Environ. Psychol. 2016, 48, 33-53. [CrossRef]

50. Clarke, D.; Murphy, C.; Lorenzoni, I. Place attachment, disruption and transformative adaptation. J. Environ. Psychol. 2018, 55, 81-89. [CrossRef]

51. Xu, D.; Qing, C.; Deng, X.; Yong, Z.; Zhou, W.; Ma, Z. Disaster risk perception, sense of pace, evacuation willingness, and relocation willingness of rural households in earthquake-stricken areas: Evidence from Sichuan Province, China. Int. J. Environ. Res. Public Health 2020, 17, 602. [CrossRef] [PubMed] 
52. Greer, A.; Binder, S.B.; Thiel, A.; Jamali, M.; Nejat, A. Place attachment in disaster studies: Measurement and the case of the 2013 Moore tornado. Popul. Environ. 2020, 41, 306-329. [CrossRef]

53. Proshansky, H.M.; Fabian, A.K.; Kaminoff, R. Place-identity: Physical world socialization of the self. J. Environ. Psychol. 1983, 3, 57-83. [CrossRef]

54. Qian, L.; Zheng, C.; Wang, J.; Pérez-Sánchez, M.d.l.Á.; López, E.P.; Li, H. Dark tourism destinations: The relationships between tourists' on-site experience, destination image and behavioural intention. Tour. Rev. ahead of print. 2021. [CrossRef]

55. Muzaini, H. On the matter of forgetting and 'memory returns'. Trans. Inst. Br. Geogr. 2014, 40, 102-112. [CrossRef]

56. Lalli, M. Urban-related identity: Theory, measurement, and empirical findings. J. Environ. Psychol. 1992, 12, 285-303. [CrossRef]

57. Tuan, Y.F. Landscapes of Fear; Pantheon: London, UK, 1979.

58. Drozdzewski, D.; Dominey-Howes, D. Research and trauma: Understanding the impact of traumatic content and places on the researcher. Emot. Space Soc. 2015, 17, 17-21. [CrossRef]

59. Fritzsche, P.; Boym, S. The Future of Nostalgia. By Svetlana Boym. New York: Basic Books, 2001. xix, 404 pp. Notes. Index. Photographs. \$35.00, hard bound. Slav. Rev. 2002, 61, 128-129. [CrossRef]

60. Legg, S. Contesting and surviving memory: Space, nation, and nostalgia in Les Lieux de Mémoire. Environ. Plan. D Soc. Space 2005, 23, 481-504. [CrossRef]

61. Dixon, J.; Durrheim, K. Dislocating identity: Desegregation and the transformation of place. J. Environ. Psychol. 2004, 24, 455-473. [CrossRef]

62. Peng, J.; Strijker, D.; Wu, Q. Place identity: How far have we come in exploring its meanings? Front. Psychol. 2020, 11, 11. [CrossRef]

63. Watson, J.W.; Tuan, Y.-F. Topophilia: A study of environmental perception, attitudes and values. Geogr. J. 1976, 142, 330. [CrossRef]

64. Foote, K.E. Shadowed Ground: America's Landscapes of Violence and Tragedy Revised and Updated; University of Texas Press: Austin, TX, USA, 2003.

65. Wang, S.; Chen, S.; $\mathrm{Xu}, \mathrm{H}$. Resident attitudes towards dark tourism, a perspective of place-based identity motives. Curr. Issues Tour. 2017, 22, 1601-1616. [CrossRef] 